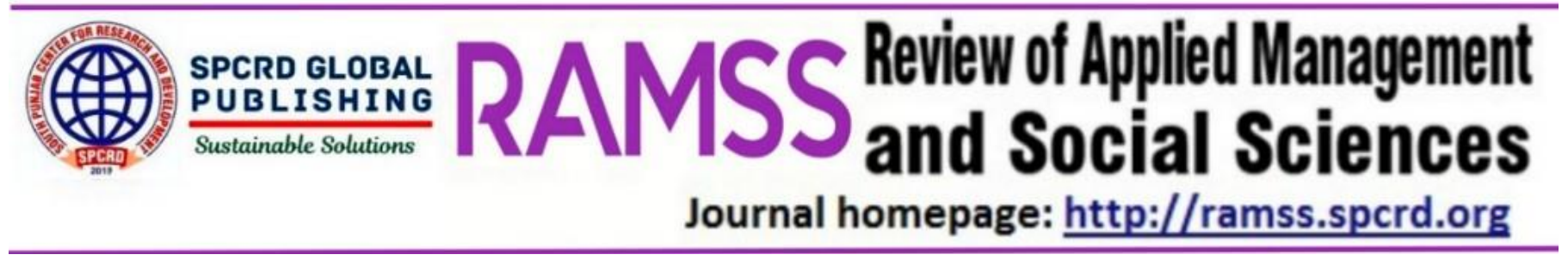

\title{
Recruitment Create Passage towards Brand Citizenship Behavior: A Conceptual Analysis
}

\author{
aAsad Ur Rehman, ${ }^{\mathrm{b}}$ Muhammad Sajid Tufail, ${ }^{\mathrm{c}}$ Muhammad Imdad Ullah, ${ }^{\mathrm{d}}$ Mohsin Altaf \\ ${ }^{a}$ Lecturer Department of Commerce, Bahauddin Zakariya University, Multan, Pakistan: asadrehmaan@bzu.edu.pk \\ bLecturer, Institute of Management Sciences BZU, Multan, Pakistan: sajidtufail@bzu.edu.pk \\ cAssistant Professor, Government College University, Faisalabad, Pakistan: imdadbzu@gmail.com \\ dAssistant Professor, UCP Business School University of Lahore, Pakistan: mohsin.iltaf@gmail.com
}

Corresponding author's email address: asadrehmaan@bzu.edu.pk

\section{ARTICLE DETAILS}

History:

Accepted: 25 December 2018

Available: online 31 December 2018

\section{Keywords:}

Brand Citizenship Behavior, Brand-

Centered Recruitment,

Employee Branding, Internal Branding

JEL Classification:

C92, D21, Go2

DOI: $10.47067 /$ ramss.v1i1.7

\section{ABSTRACT}

The Brand citizenship behavior (BCB) is relatively a new aspect in marketing literature. Researchers have given a label of $\mathrm{BCB}$ to the discretionary behavior that employees' exhibit for the successful delivery of brand promise. In internal branding, the role of an employee is recognized as critical in delivering the service as promised by the brand. As practitioners and academicians argue that, an employee's brand-aligned behavior that goes above and beyond the job responsibility can be an asset for the company. So far skills competencies of employees are difficult for competitors to imitate. Drawing on employees brand-aligned behavior to build the strong organizational brand(s) this study conceptualized that, the successful implementation of internal branding doctrine could be strengthened by brand-centered recruitment practice. This study found that fair recruitment process in an organization can build an employees' deeper understanding of the brand and the role they play would enhanced the brand citizenship behavior.

(C) 2018 The authors. Published by SPCRD Global Publishing. This is an open access article under the Creative Commons Attribution-

NonCommercial 4.0

\section{Introduction}

A new paradigm in brand management is an internal branding, which develops a contemporary brand experience and provides value to stakeholders(Punjaisri \& Wilson, 2011; Saleem \& Iglesias, 2016). According to King and Grace (2009),internal branding has been recognized as a way for companies to get the holy grail of competitive advantage. It is assumed that when aligning the behaviors of employees with company's brand value, the paradoxes could be minimized among brand promise and brand delivery (Shaari, Salleh, \& Hussin, 2015), thus eventually maximize the satisfaction and brand experience of customers(Burmann \& Zeplin, 2005).Hence, internal branding leads to align behaviors of 
employees with the company's brand considered as acute factor to attract the target customers.

Scholar documented that employees' brand behaviors (i.e. in role and extra-role)considered as significant to build a strong brand(King \& Grace, 2010).Employee's in role brand behaviors is related to prescribed rules and regulation by the company based on their role as brand representative on the other side extra role behavior has focused on an employee's willingness to exert extra effort that goes beyond the prescribed brand roles and enhance the company's good repute (Morhart, Herzog, \& Tomczak, 2009; De Chernatony, 2002). The employee's extra role behavior contributes to customers' loyalty and enhances the organization's performance (Porricelli, Yurova, Abratt, \& Bendixen, 2014). Shaari, Salleh, and Hussin (2012) asserted that the employee's willingness to put forth extra role behavior is seen as vital for the successful delivery of brand promise. Thus, employees' extra role brand behavior is also known as brand citizenship behavior (BCB) (Henkel, Tomczak, Heitmann, \& Herrmann, 2007; Burmann\&Zeplin, 2005). Therefore, notion of BCB is referred as "the employees' voluntary basis to project a number of generic employee behaviors that enhances the corporate brand identity" (Burmann\&Zeplin, 2005, p. 282).

Research has shown that companies develop the brand to identify and differentiate its products and services from their competitors (Keller, Parameswaran, \& Jacob, 2011). However, Schultz and De Chernatony (2002), assert that the success of branding largely relies on employees' extra role behaviors in delivering the brand to external stakeholders. Similarly, Burmann and Zeplin (2005) stated that organizations' brand values and performances are possibly enhanced by the good liaison of employees' with customer. Hence, employees' extra role behaviors, according to the company's brand values, is considered the major determinant of BCB.

Most of studiesin relation to employees brand citizenship behavior have discussed the role of leadership style, empowerments of employees, markets manipulation, and the organizations' brand identities (Henkel, Tomczak, Heitmann, \& Herrmann, 2007). Scholars argued that in the discipline of organizational behavior the construct human resource management is an important predictor of brand(s) citizenship behavior (Chang, Chiang, \& Han,2012). But limited studies have addressed the human resource practices such as brand-centered recruitment, the key process of talent recruiting in a company, could enhance the employees' brand citizenship behavior. It is found that quite little researches, such as Burmann and Zeplin (2005) andBurmann, Zeplin and Riley(2009), has discussed the significant influence of brand-centered recruitment on employees' BCB.

In addition, Research results haves shown that brand-centered recruitment can create primary base for companies to develop the competitive advantages (Collins \& Clark, 2003). But, previous scholars did not confer in detail how recruitment practice might increases the employees' behavior or describing the expected brand related performance from employee. Thus, this study proposes an attempts to find the effect of brand-centered recruitment on the employees brand citizenship behavior.

\section{Literature Review}

\subsection{The Concept of Brand-Centered Recruitment}

Recruitment is considered as one of the most important human resource practices which has influenced the behaviors of individuals (i.e. employees) to deliver the company's brand promise. In essence, recruitment is a planned effort to appeal individuals whose profile and skills set matched with the company's job requirement (Punjaisri, Wilson, \& Evanschitzky, 2008). It is assumed that when such individuals are trained, they could perform efficiently as desired by the company (Mangold \& Miles, 
2007). Prior researches expose how recruitment practice influences employees' behavior with respect to the nature of job (Saifalislam, Osman, \& AlQudah, 2014; Zhang, Di Fan, \& Zhu, 2014). Literature on branding has shown that, relatively limited work is addressed to show that how recruitment practices increase employee's brandcitizenshipbehavior.For instance, scholars (Aurand, Gorchels, and Bishop, 2005; Burmann and Zeplin, 2005; King and So, 2013) have asserted the construct brand-centered recruitment as imperative predictor of employee(s) BCB.

Jiang and Iles (2011) stated that the recruitment process is vital for communicating prospective employees for what the organization stands for and nevertheless, what behavior is expected to be delivered by the company's brand. Evidently, King and So (2013), claimed that brand-centered recruitment has instigated an employees' behavior according to organization's brand values to build-up strong brand. Therefore, brand-centered recruitment practice encourages employees to align their behavior with respect to pro-brand manner.

The qualitative and quantitative study of MacLaverty et al. (2007), however, revealed that in corporate business the executives were responsible for internal branding within their organizations, they shown the importance of recruitment practices in internal brand building. According to these researchers, brand-centered recruitment found to be the good practice to constantly build the skill(s)among employees to deliver the brand promise. Similarly, the findings of Chang et al. (2012) advocate that, companies at large give attention to recruit those talented individuals who have positive attitude toward the brand citizenship behavior. However, these researchers did not discuss the employees' perspective related to the recruitment that may affect behaviors but most of studies focused on the recruitment practices in a management perspective as a part of internalization.

Previous literature documents that via certain human resource practice, such as recruitment process can motivate employees to affirm the brand-centered behavior(Aurand et al., 2005).Similarly, Burmann and Zeplin (2005) argued that brand-centered recruitment may commit employee behavior towards brand identity that is the strength of internal branding. Thus, brand-centered recruitment enables employees to perform the pro-brand behavior, which might enrich overall brand performance of the company.

\subsection{The relationship between Brand-Centered Recruitment and Brand Citizenship Behavior}

The prior studies in internal branding endeavor to probe the influence of human resource practices to stimulate employees' brand-citizenship behavior. It is assumed that human resource practice such as brand-centered recruitment is likely to communicate an accurate, convincing, and significant brand message towards the target individuals. For instance the finding of Bolino and Turnley (2003)reveals that; firstly, companies may attempt to elicit more citizenship behavior among their employees by selecting those individuals who are generally predisposed to be engaged in citizenship. Secondly, the individuals who have exhibited high levels of involvement on extracurricular activities in addition to their core obligations might also be inclined to prompt extra role behavior as future employees.

Furthermore, Burmann and Zeplin (2005) argued thatbrand centered-recruitment practice proposes that how an individual can be fitted with company's brand to deliver the successful brand promise. As Ind (1998) stated that recruitment is a part of corporate brand management which helps managers to select those employees who are best fit with company brand. However, it is seen that in many companies during the recruitment process, the alignment of individual values with the company 
brand values is often neglected. This might be due to the fact that individual evaluation process to fit with company brand may not be that easy to be managed as is thought of. This is because in recruitment process an adoption of appropriate screening techniques maybe critical, however. On the other side, the possible approach is to allow individuals to initially attach with experienced employees to learn from them how to create an appropriate behavior afore joining the company _ help to better internalize the brand values.

The study of Gotsi and Wilson (2001) investigated factors that are important for companies to fulfils their promise with target audience and how employees perform their duties to achieve the company's promise. The finding of the study revealed that human resource practices such as recruitment policies are to be aligned with company's brand values to elude any conflict promise. Similarly, Turek and Wojtczuk-Turek (2015) claimed that a well-defined practice of recruitment creates a positive perception among employees to prompt their willingness to undertake extra-role behavior. Hence, scholars suggested that recruitment has sought to look beyond the job to identify the employees' extra-role behavior such as BCB(Begum, Zehou, \& Sarker, 2014).

It is seem truism that employees' perception about fair recruitment process has encouraged them to produce positive extra role behavior, which are consistent with Chang et al. (2012) who applied social exchange theory in such a way that "employees who believes that the reciprocal exchange of valued benefits can occur are more willing to establish exchange relations with other colleagues and the organization. In that situation, mutual relationships between employees and the organization can be established as positive, long-term, and interactive relations that contribute to organizational performance” (p. 629).In addition, researchers recognized that human resource practice such as brand centered recruitment may influence employees towards the development of brand citizenship behaviors(Burmann \& Zeplin, 2005; Burmann, Zeplin, \& Riley, 2009a; Ravens, 2014; Sepahvand \& Sepahvand, 2013). For instance, as Cropanzana, Bowen, and Gilliland (2007), suggested that the individual who are chosen by the fair recruitment process might have the positive attitude about the company and spread good word of mouth with friends and family, opposite to those individuals who faced unfair recruitment. Furthermore, when an individuals' has joined company on the base of a fair recruitment method, they are more willing to perform responsibilities honestly and create trustful relations with colleagues.

Based on above discussion, the study thereby develops a proposition to examine, in specified array of approach, the fact of how do the brand centered recruitment may strengthen the employees' brand citizenship behavior.

Proposition: The likelihood of employee brand citizenship behavior will be increased based on the fair recruitment practices.

\section{Conceptual Model}

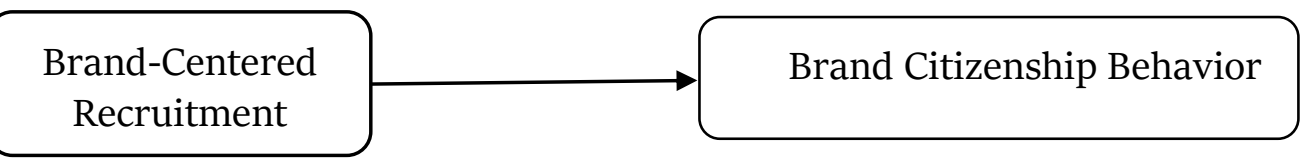

Figure 1: Brand-Centered Recruitment Relation with Employees’ BCB 
On the base of social exchange theory presented by Blau (1964), this study develops conceptual model that exhibits, brand-centered recruitment practice strengthen the employees' understanding towards brand citizenship behavior. However, brand-centered recruitment practice attract those individuals whose personal values are well-suited with the company's brand values (King \& So, 2013). Hence, it is seem truism that brand-centered recruitment provide foundation to shape up the individuals according to pro-brand behavior(Chang et al., 2012) and encourage them towards the extra role behavior such as BCB(Burmann et al., 2009a).

\section{Conclusion}

This study proposed that brand-centered recruitment is seemed to be an essential practice to enhance the employees' brand citizenship behavior. However, academician and consultant do claim that fair brand-centered recruitment process can build a supportive job atmosphere where employees are encouraged towards brand altruist, esprit and exhibit brand citizenship behavior, which develop the grounds for improvising the overall brand performance. It is assumed on the bases of social exchange theory that brand-centered recruitment practice is best to increase employees' BCBs. This is because, fair recruitment process has encouraged employees to align their behavior with company brand values for the successful delivery of brand promise. It is observed, especially service companies are failed to build strong brand due to an in appropriate recruitment and selection of employees. However, on the other side brand-centered recruitment process have provided the foundation for companies to nurture the good brand image and motivate employees towards the BCB. In addition, the brand-centered recruitment prompt to be minimized the issues of internal branding and backing individuals to deliver an adequate brand promise. The horizon of employees' brand citizenship behavior may not be limited to the brand-centered recruitment, there might be probed other new aspects to establish the phenomena of $\mathrm{BCB}$. To sum it up, brand citizenship behavior seems to be positively enhanced by the brand-centered recruitment technique, thus in conclusion brand-centered recruitment is conspicuous approach which is to enable company to achieve sustainable competitive advantage.

\section{References}

Aurand, T. W., Gorchels, L., \&Bishop, T. R. (2005). Human resource management's role in internal branding: an opportunity for cross-functional brand message synergy. Journal of Product \& Brand Management, 14(3), 163-169.

Begum, S., Zehou, S., \&Sarker, M. A. H. (2014). Investigating the Relationship between Recruitment \& Selection Practice and OCB Dimensions of Commercial Banks in China. International Journal of Academic Research in Management (IJARM), 3 (2), 146-154.

Blau, P. M. (1964). Exchange and power in social life: Transaction Publishers.

Bolino, M. C., \&Turnley, W. H. (2003). Going the extra mile: Cultivating and managing employee citizenship behavior. The Academy of Management Executive, 17(3), 60-71.

Burmann, C., \&Zeplin, S. (2005). Building brand commitment: A behavioural approach to internal brand management. The Journal of Brand Management, 12(4), 279-300.

Burmann, C., Zeplin, S., \&Riley, N. (2009a). Key determinants of internal brand management success: An exploratory empirical analysis. Journal of Brand Management, 16(4), 264-284.

Chang, A., Chiang, H.-H., \&Han, T.-S. (2012). A multilevel investigation of relationships among brandcentered HRM, brand psychological ownership, brand citizenship behaviors, and customer satisfaction. European Journal of Marketing, 46, 626-662.

Collins, C. J., \&Clark, K. D. (2003). Strategic human resource practices, top management team social networks, and firm performance: The role of human resource practices in creating organizational competitive advantage. Academy of management Journal, 46(6), 740-751. 
Cropanzana, R., Bowen, D. E., \&Gilliland, S. W. (2007). The management of organizational justice. The Academy of Management Perspectives, 34-48.

Gotsi, M., \&Wilson, A. (2001). Corporate reputation management:“living the brand”. Management Decision, 39(2), 99-104.

Henkel, S., Tomczak, T., Heitmann, M., \&Herrmann, A. (2007). Managing brand consistent employee behaviour: relevance and managerial control of behavioural branding. Journal of Product \& Brand Management, 16(5), 310-320.

Ind, N. (1998). An integrated approach to corporate branding. Journal of Brand Management, 5(5), 323329.

Jiang, T., \&Iles, P. (2011). Employer-brand equity, organizational attractiveness and talent management in the Zhejiang private sector, China. Journal of Technology Management in China, 6, 97-110. doi: 10.1108/17468771111105686

Keller, K. L., Parameswaran, M., \&Jacob, I. (2011). Strategic brand management: Building, measuring, and managing brand equity: Pearson Education India.

King, C., \&Grace, D. (2009). Employee based brand equity: A third perspective. Services Marketing Quarterly, 30(2), 122-147.

King, C., \&Grace, D. (2010). Building and measuring employee-based brand equity. doi: $10.1108 / 03090561011047472$

King, C., \&So, K. K. F. (2013). Enhancing Hotel Employees’ Brand Understanding and Brand-Building Behavior in China. Journal of Hospitality \& Tourism Research, XX, 1-25. doi: 10.1177/1096348013491602

MacLaverty, N., McQuillan, P., \&Oddie, H. (2007). Internal branding best practices study. Canadian Marketing Association. Retrieved December, 2, 2008.

Mangold, W. G., \&Miles, S. J. (2007). The employee brand: Is yours an all-star? Business Horizons, 50(5), 423-433.

Morhart, F. M., Herzog, W., \&Tomczak, T. (2009). Brand-specific leadership: Turning employees into brand champions. Journal of Marketing, 73(5), 122-142.

Porricelli, M. S., Yurova, Y., Abratt, R., \&Bendixen, M. (2014). Antecedents of brand citizenship behavior in retailing. Journal of Retailing and Consumer Services, 21(5), 745-752.

Punjaisri, K., Wilson, A., \&Evanschitzky, H. (2008). Exploring the Influences of Internal Branding on Employees' Brand Promise Delivery: Implications for Strengthening Customer-Brand Relationships. Journal of Relationship Marketing, 7(4), 407-424.

Punjaisri, K., \&Wilson, a. M. (2011). Internal branding process : Key mechanisms, outcomes and moderating factors. doi: 10.1108/03090561111151871

Ravens, C. (2014). Internal Brand Management in an International Context. doi: 10.1007/978-3-65800754-6

Saifalislam, K., Osman, A., \&AlQudah, M. (2014). Human Resource Management Practices: Influence of recruitment and selection, and training and development on the organizational performance of the Jordanian Public University. organization, 3, 1.o8873.

Saleem, F. Z., \&Iglesias, O. (2016). Mapping the domain of the fragmented field of internal branding. Journal of Product \& Brand Management, 25(1), 43-57.

Schultz, M., \&De Chernatony, L. (2002). Introduction: The challenges of corporate branding. Corporate Reputation Review, 5(2-3), 105-112.

Sepahvand, R., \&Sepahvand, S. (2013). Investigating the effectiveness of Brand-centered human resource management on clients' satisfaction of company's brand with concentrating on Black Box processes. 5, 979-992.

Shaari, H., Salleh, S. M., \&Hussin, Z. (2012). Relationship between Brand Knowledge and Brand 
Rewards, and Employees' Brand Citizenship Behavior: The Mediating Roles of Brand Commitment. International Journal of Business and Society, 13(3), 335.

Shaari, H., Salleh, S. M., \&Hussin, Z. (2015). The Effect of Brand Leadership Styles on Employees' Brand Citizenship Behavior. Asian Social Science, 11, 86-92. doi: 10.5539/ass.v11n18p86

Turek, D., \&Wojtczuk-Turek, A. (2015). HRM Practices Influence Organizational Citizenship Behavior? Mediating The Role Of Person-Organizational Fit.Managing Intellectual Capital and Innovation for Sustainable and Inclusive Society, Bari, Italy, 2219-2233.

Vallaster, C., \&de Chernatony, L. (2006). Internal brand building and structuration: the role of leadership. European Journal of Marketing, 40(7/8), 761-784.

Zhang, M., Di Fan, D., \&Zhu, C. J. (2014). High-performance work systems, corporate social performance and employee outcomes: Exploring the missing links. Journal of business ethics, $120(3), 423-435$. 